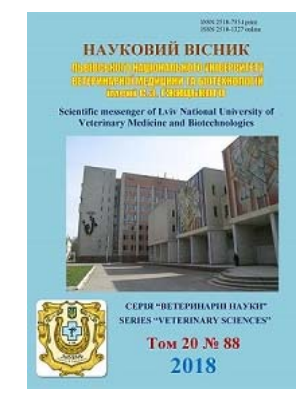

Науковий вісник Яьвівського національного університету ветеринарної медицини та біотехнологій імені С.З. Гжицького

\author{
Scientific Messenger of Lviv National University \\ of Veterinary Medicine and Biotechnologies
}

UDC 619: 639.2.09; 639.3.09

\title{
Veterinary and sanitary evaluation of frozen fish imported into Ukraine for presence of antibacterial substances residues
}

\author{
Z.V. Malimon ${ }^{1}$, M.D. Kukhtyn ${ }^{2}$, N.E. Grynevych ${ }^{3}$, I.M. Azyrkina ${ }^{1}$ \\ ${ }^{1}$ State Research Institute for Laboratory Diagnostics and Veterinary and Sanitary Expertise, Donetska, Kyiv, Ukraine \\ ${ }^{2}$ Ternopil Ivan Puluj National Technical University, Department of Food Technologies, Ternopil, Ukraine \\ ${ }^{3}$ Bila Tserkva National Agrarian University, Bila Tserkva, Ukraine
}

\section{Article info}

Received 26.07.2018

Received in revised form 27.08.2018

Accepted 29.08.2018

State Research Institute for Laboratory Diagnostics and Veterinary and Sanitary Expertise Donetska, Str., 30, Kyiv, 02000, Ukraine.

E-mail: z_malimon@ukr.net

Ternopil Ivan Puluj National Technical University, Department of Food Technologies, Ruska Str., 56, Ternopil, 46001, Ukraine. Тел.: +38-097-23-92-057 E-mail:kuchtynnic@gmail.com

Bila Tserkva National Agrarian University, Soborna sq., 8/1, Bila Tserkva, 09111, Ukraine. Тел.: +38-050-532-87-16 E-mail:gnatbc@ukr.net
Malimon, Z.V., Kukhtyn, M.D., Grynevych, N.E., \& Azyrkina, I.M. (2018). Veterinary and sanitary evaluation of frozen fish imported into Ukraine for the presence of antibacterial substances residues. Scientific Messenger of Lviv National University of Veterinary Medicine and Biotechnologies, 20(88), 36-41. doi: 10.32718/nvlvet8806

Significant and unlimited use of antibacterial drugs, leads to their accumulation in the aquatic environment, tissues of fish, and, accordingly, in fish products. The problem of residual amounts of antibacterial drugs in raw materials and food products is relevant not only in Ukraine but also in the whole world. The purpose of the work was to conduct monitoring researches of frozen fish on the content of antibacterial substances residues. The presence of residual amounts of anti-bacterial substances was carried out by a screening method for the determination of antibiotics in products of animal origin PX/MC/MC and the microbiological method. It was established that in the trading network frozen fish was sold, which contained $10.5 \pm 0.3 \%$ of the remainder of the antibacterial substance. The most frequently imported frozen fish in Ukraine were antimicrobials from the group of antibiotics of the first generation aminoglycosides (apramicin, kanamycin, gentamicin, spectinomycin, paromomycin) $-46.4 \pm 0.7 \%$ of cases and supply dixic acid at $19.0 \pm 0.2 \%$. In $11 \%$ of cases, in frozen fish, the remains of sulfamide antimicrobial agents - sulfaphenazole. Antibiotics of the penicillin number: penicillin, amoxicillin and nafcillin, despite the presence of antimicrobial activity, mainly in relation to gram-positive micro flora, were found in the total number of $11.1 \pm$ $0.2 \%$ of cases. In the smallest number of samples of frozen fish, antibiotics of the tetracycline group - tetracycline in $1.6 \pm 0.1 \%$ of cases were detected. The largest numbers of antibacterial substances were detected from $11.2 \pm 0.2$ to $14.4 \pm 0.2 \%$ for argentine and flatfish species. In such pelagic species of fish as lakerda, mackerel, capelin and mackerel, antibiotics were detected in an equal number, in about $10 \%$ of the examined samples. Almost $8 \%$ of samples of frozen fish like salmon contain antibacterial substances. In addition, equally in $6.3 \pm 0.2 \%$ of the examined samples, veterinary drugs were found in oceanic fish such as herring and red-eyed fish. In the smallest amount, up to 5\% showed antimicrobial substances in sea fish such as dorado and pink salmon. The presences of antibacterial substances in the investigated fish samples, which are not stipulated by the EU Regulation No. 37/2010, have been identified. Consequently, there was a need to provide in the "State monitoring plan for residues of veterinary drugs, pollutants and toxicants in products of animal origin" a study to determine the residual amounts of antibacterial substances and antibiotics to increase the safety of fish imported into Ukraine.

Key words: frozen fish, antibiotics, antibacterial substances, residual quantities, safety.

\section{Ветеринарно-санітарна оцінка замороженої риби, імпортованої в Україну, на наявність залишків антибактеріальних субстанцій}

\author{
3.В. Малімон ${ }^{1}$ М.Д. Кухтин ${ }^{2}$, Н.С. Гриневич ${ }^{3}$, І.М. Азиркіна ${ }^{1}$ \\ ${ }^{1}$ Державний науково-дослідний інститут з лабораторної діагностики та ветеринарно-санітарної експертизи, \\ м. Київ, Україна \\ ${ }^{2}$ Тернопільський національний технічний університет імені I. Пулюя, м. Тернопіль, Украӥна \\ ${ }^{3}$ Білочерківський національний аграрний університет, м. Біла Церква, Украӥна
}


Значне і необмежене застосування антибактеріальних препаратів, призводить до накопичення їх у водному середовищі, тканинах риби, і відповідно в рибних продуктах. Проблема залишкових кількостей антибактеріальних препаратів у сировині та харчових продуктах є актуальною не тільки в Україні, а й у иілому світі. Метою роботи було провести моніторингові дослідження замороженої риби на вміст залишків антибактеріальних субстанцій. Наявність залишкових кількостей антибактеріальних субстаниій проводили скринінговим методом визначення антибіотиків у продукиї тваринного походження РХ/МС/МС та мікробіологічним методом. Встановлено, шзо у торговельній мережі реалізується заморожена риба, яка у 10,5 \pm 0,3\% містила залитки антибактеріальних субстаниї. Найчастіше у імпортованій в Украӥну замороженій рибі виявляли протимікробні препарати із групи антибіотиків аміноглікозидів I-II покоління (апраміцин, канаміцин, гентаміцин, спектиноміцин, паромоміцин, дигідрострептомі-

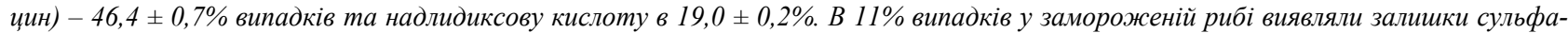
мідних протимікробних препаратів - сульфафеназол. Антибіотики пеніцилінового ряду: пеніцилін, амоксицилін і нафцилін, незважаючи на наявність протимікробної дії переважно щзодо грампозитивної мікрофлори, виявлялися у сумарній кількості 11,1 $\pm 0,2 \%$ випадків. У найменшій кількості проб замороженої риби виявляли антибіотик тетрациклінової групи - тетрациклін в 1,6 \pm 0,1\% випадків. У найбільшій кількості виявляли антибактеріальні субстанції від 11,2 \pm 0,2 до 14,4 \pm 0,2\% у видів риби аргентина та камбала. У таких пелагічних видів риби, як лакерда, скумбрія, мойва і макрель виявляли антибіотичні препарати в однаковій кількості, приблизно в 10\% випадків досліджених проб. Практично 8\% проб такої замороженої риби, як салака і сайра містили антибактеріальні субстанції. Також порівну по 6,3 \pm 0,2\% досліджених проб виявляли ветеринарні препарати, у таких океанічних риб, як оселедець і червоноока. У найменшій кількості до 5\% виявляли антимікробні субстаниї у таких морських риб, як дорадо і горбуша. Виявлено наявність антибактеріальних субстаниій у досліджених пробах риби, визначення, яких не передбачено Регламентом СС № 37/2010. Отже, виникла необхідність передбачити у “Плані державного моніторингу залишкових кількостей ветеринарних препаратів, забруднювачів та токсикантів у продуктах тваринного походження” дослідження з визначення залишкових кількостей антибактеріальних субстаниій і антибіотиків для підвищення безпечності риби, імпортованої в Украӥну.

Ключові слова: заморожена риба, антибіотики, антибактеріальні субстаниії, залишкові кількості, безпечність.

\section{Ветуп}

Нині значну роль у вирішенні проблеми забезпечення населення продуктами тваринного походження займає галузь рибництва (Usydus et al., 2008). Суттєвим чинником, який стримує розвиток рибництва $є$ інфекційні захворювання, для лікування та профілактики яких використовують антибактеріальні препарати (антибіотики, сульфаніламіди, нітрофурани, дезінфектанти, тощо) (Kosenko et al., 2002; Grynevych et al., 2018; Kovalenko et al., 2018). Значне і необмежене застосування антибактеріальних препаратів призводить до накопичення їх у водному середовищі, тканинах риби і відповідно в рибних продуктах (Samanidou and Evaggelopoulou, 2007; Akinbowale et al., 2007; Rico et al., 2012; Zhang et al., 2013; Bayer et al. 2017). Так, дослідники (Topic Popovic et al., 2010; Chen, 2014; Bayer et al., 2017) виявляли антибактеріальні препарати різних груп у рибі в Україні, Китаї, Хорватії, Австралії. У дослідженнях, проведених в (Bayer et al., 2017) виявляли залишки ветеринарних препаратів нітрофуранового ряду, сульфаніламіди, антибіотики у рибі в різних регіонах України. При цьому тільки близько 40\% зразків сировини містили залишкові кількості сульфаніламідних препаратів в межах 50$70 \%$ ГДК.

Використання великої кількості антибіотиків може призвести до появи антибіотикорезистентних бактерій у водному середовищі аквакультури, збільшенні резистентності до антибіотиків у риб'ячих патогенів, а також передачі детермінант резистентності патогенам людини (Bhowmick et al., 2008; Grigorakis and Rigos, 2011; Kukhtyn et al., 2017).

Ринок морської риби в Україні представлений в основному імпортною, яка поступає до нас в замороженому вигляді за температури $-12 \ldots-18^{\circ} \mathrm{C}$. Водночас згідно з "Планом державного моніторингу залишків ветеринарних препаратів та забруднювачів у живих тваринах i необроблених харчових продуктах тваринного походження" визначення залишкових кількостей ветеринарних препаратів передбачено у рибі власного виробництва згідно Регламенту ЄС 37/2010 "Про фармакологічно активні речовини та їх класифікація відносно максимальних допустимих кількостей в харчових продуктах тваринного походження". Заморожена риба, яка імпортується в Україну, не досліджується на наявність залишкових кількостей антибактеріальних субстанцій.

Отже, проблема залишкових кількостей антибактеріальних препаратів у сировині та харчових продуктах $є$ актуальною не тільки в Україні, а й у цілому світі.

Метою роботи було провести моніторингові дослідження замороженої риби на вміст залишків антибактеріальних субстанцій.

Для досягнення даної мети були поставлені такі завдання:

- дослідити залишки заборонених антибактеріальних субстанцій у замороженій рибі, імпортованій в Україну;

- провести ідентифікацію виявлених залишкових антибактеріальних субстанцій і антибіотиків у замороженій рибі;

- визначити види замороженої риби, які найчастіше містила залишки антибактеріальних субстанцій i антибіотиків.

\section{Матеріал та методи досліджень}

Робота виконана в Державному науководослідному інституті з лабораторної діагностики та ветеринарно-санітарної експертизи (ДНДІЛДВСЕ), в Дніпровській регіональній державній лабораторії Державної служби України з питань безпечності харчових продуктів та захисту споживачів та Тернопільській дослідній станції Інституту ветеринарної медицини НААН.

Проведено дослідження проб замороженої риби. Наявність залишкових кількостей антибактеріальних субстанцій проводили скринінговим методом визначення антибіотиків у продукції тваринного походження $\mathrm{PX} / \mathrm{MC} / \mathrm{MC}$ та мікробіологічним методом 
(Novozhytska et al., 2014). Визначено 50 антибактеріальних субстанцій: сульфагуанідин, сульфацетамід, сульфапіридин, сульфадіазин, сульфаметоксазол, сульфатіазол, сульфамеразин, сульфаметізол, сульфабензамід, сульфаметазин, сульфхіноксолін, сульфадоксин, сульфадиметоксин, пеніцилін $\mathrm{G}$, цефалексин, ампіцилін, пеніцилін V, амоксицилін, триметопрім, нафцилін, оксацилін, йозаміцин, спіраміцин, налідиксова кислота, флумекін, оксалінова кислота, норфлоксацин, ципрофлоксацин, спектиноміцин, данофлоксацин, енрофлоксацин, марбофлоксацин, сарафлоксацин, дифлоксацин, лінкоміцин, гентаміцин, доксициклін, хлортетрациклін, тетрациклін, оситетрациклін, канаміцин, апраміцин, стрептоміцин, дигідрострептоміцин, паромоміцин, сульфамоксол, сульфафеназол, сульфаметоксипіридазин, сульфамонометоксин, тіамулін.

Статистичну обробку результатів дослідження здійснювали за загальновизнаними методами варіаційної статистики з використанням програми Statistic 6. Використовували непараметричні методи досліджень (критерій Уілкоксона, Манна-Уітні). Визначали середнє арифметичне - $x$, стандартну похибку середньої величини - SE. Різницю між порівнюваними величинами вважали достовірною при $\mathrm{P} \leq 0,05$.

\section{Результати та їх обговорення}

Результати досліджень щодо визначення залишків антибактеріальних препаратів у замороженій рибі наведено на рис. 1.

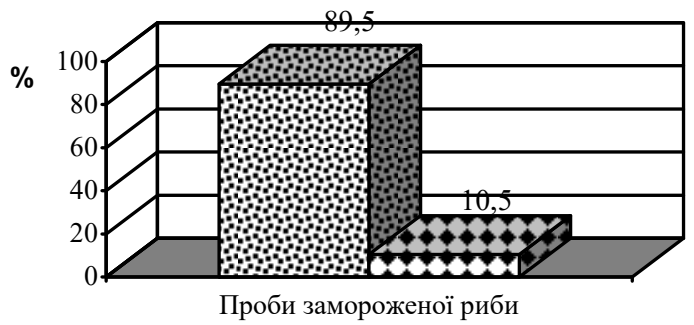

$$
\begin{aligned}
& \text { 由Відсутність антибактеріальних субстанцій у рибі } \\
& \text { घНаявсність антибактеріальних субстанцій }
\end{aligned}
$$

Рис. 1. Виявлення позитивних проб за вмістом антибактеріальних субстанцій у замороженій рибі

Як видно 3 даних рис. 1, з 100 досліджених проб замороженої риби, кількість позитивних зразків, які містили антибактеріальні субстанції, становила $10,5 \pm 0,3 \%$. Це вказує на те, що дану рибу вирощували із застосуванням антибактеріальних препаратів або їх використовували під час заморожування для зупинення розвитку мікрофлори і продовження термінів зберігання.

Отже, закордонні виробники та імпортери замороженої риби не завжди дотримуються санітарногігієнічних вимог щодо застосування і каренції антимікробних засобів під час іiї вирощування або заморожування.

Водночас, національним законодавством не передбачено дослідження замороженої риби на залишки ветеринарних препаратів та забруднювачів у аквакультурах (риба), яка поступає на український ринок ізза кордону.

На рис. 2 наведено дані дослідження щодо ідентифікації наявних антибактеріальних субстанцій у замороженій рибі. 3 рис. 2 видно, що найчастіше у замороженій рибі, яка імпортована в Україну, виявляли антибактеріальну субстанцію налідиксову кислоту в $19,0 \pm 0,2 \%$ випадків досліджених проб. Ветеринарний антибіотик із групи аміноглікозидів - апраміцин виявляли у рибі в $15,9 \pm 0,2 \%$ випадків. Доволі часто виявляли у рибі інший антибіотик-аміноглікозид канаміцин у $14,3 \pm 0,2 \%$ випадків. Понад $11 \%$ виділяли субстанцію із групи сульфамідних протимікробних препаратів - сульфафеназол, який також проявляє широкий спектр антимікробної дії на мікроорганізми різних груп. Аміноглікозид гентаміцин і ветеринарний антибіотик тіамулін виявлялися в однаковій кількості досліджених проб замороженої риби по 6,3 0,1\%. Антибіотики пеніцилінового ряду: пеніцилін, амоксицилін i нафцилін, незважаючи на наявність протимікробної дії переважно щодо грампозитивної мікрофлори, виявлялися у сумарній кількості 11,1 0,2\% випадків. Дигідрострептоміцин і стрептоміцин, які також відносяться до антибіотиківаміноглікозидного ряду виявлялися в $6,4 \pm 0,3 \%$ випадків. У найменшій кількості проб замороженої риби виявляли антибіотик тетрациклінової групи - тетрациклін в $1,6 \pm 0,1 \%$ випадків.

Загалом з одержаних даних випливає, що найчастіше у імпортованій в Україну замороженій рибі виявляли протимікробні препарати із групи антибіотиків аміноглікозидів I-II покоління (апраміцин, канаміцин, гентаміцин, спектиноміцин, паромоміцин, дигідрострептоміцин) - 46,4 \pm 0,7\% випадків. Ймовірно через широкий спектр їхньої бактерицидної дії на більшість грампозитивних i грамнегативних мікроорганізмів, збудників харчових інфекцій та мікроорганізмів, що спричиняють вади риби. Крім того, практично в 20\% випадків виявляли налідиксову кислоту, що ймовірно пов'язано з доброю іiі активністю щодо бактерій родини Enterobacteriaceae. Регламент комісії СС № 37/2010 "Про фармакологічно активні речовини та їх класифікації відносно максимальних допустимих кількостей в харчових продуктах тваринного походження" не регламентує залишки налідиксової кислоти.

На рис. 3 наведено дослідження риби, яка найчастіше містила антибактеріальні субстанції. Як видно 3 даних рис. 3, частота виявлення антибактеріальних препаратів у замороженій рибі різнилася між видами. У найбільшій кількості виявляли антибактеріальні субстанції від 11,2 \pm 0,2 до 14,4 \pm 0,2\% у видів риби аргентина та камбала. У таких пелагічних видів риби, як лакерда, скумбрія, мойва і макрель виявляли антибіотичні препарати в однаковій кількості, приблизно в 10\% випадків досліджених проб. Практично 8\% проб такої замороженої риби, як салака і сайра містили антибактеріальні субстанції. Також порівну по 6,3 0,2\% досліджених проб виявляли ветеринарні препарати, у таких океанічних риб, як оселедець і червоноока. 


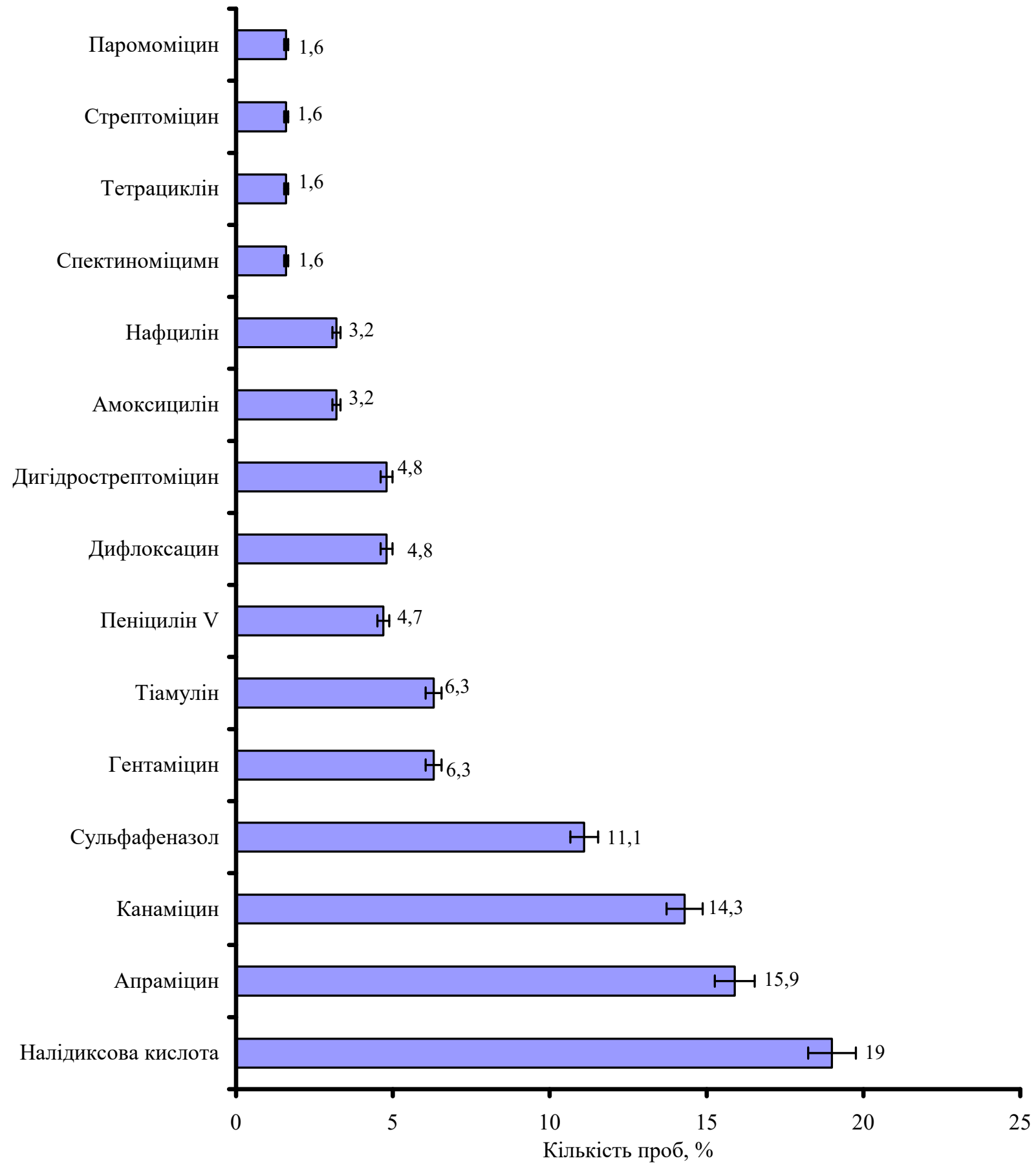

Рис. 2. Найбільш поширені антибактеріальні субстанції, виявлені у замороженій рибі

У найменшій кількості до 5\% виявляли антимікробні субстанції у таких морських риб, як дорадо і горбуша.

Отже, одержані дані досліджень вказують на те, що види замороженої риби, які поступають в Україну, за частотою забруднення антибактеріальними препаратами відрізняються між собою. Найчастіше містили залишки антибактеріальних препаратів - це види риб аргентина i камбала та практично в $3-4,5$ раза $(\mathrm{P}<0,05)$ менше виявляли їх у видів риб дорадо i горбуша.
Загалом, підсумовуючи дослідження, варто зазначити таке. Заморожена риба, яка поступає на український ринок, не в повному обсязі досліджується на виявлення залишкових кількостей ветеринарних препаратів, забруднювачів та токсикантів, як наслідок нами виявлено $10,5 \pm 0,3 \%$ проб риби, що містили залишки антибактеріальних субстанцій і антибіотиків. Отримані нами результати узгоджуються 3 даними дослідників (Bayer et al., 2017), які виявляли у харчових продуктах антибіотики, сульфаніламіди та нітрофуранові препарати, під час проведення Плану державного моніторингу в 2015-2016 pp. 


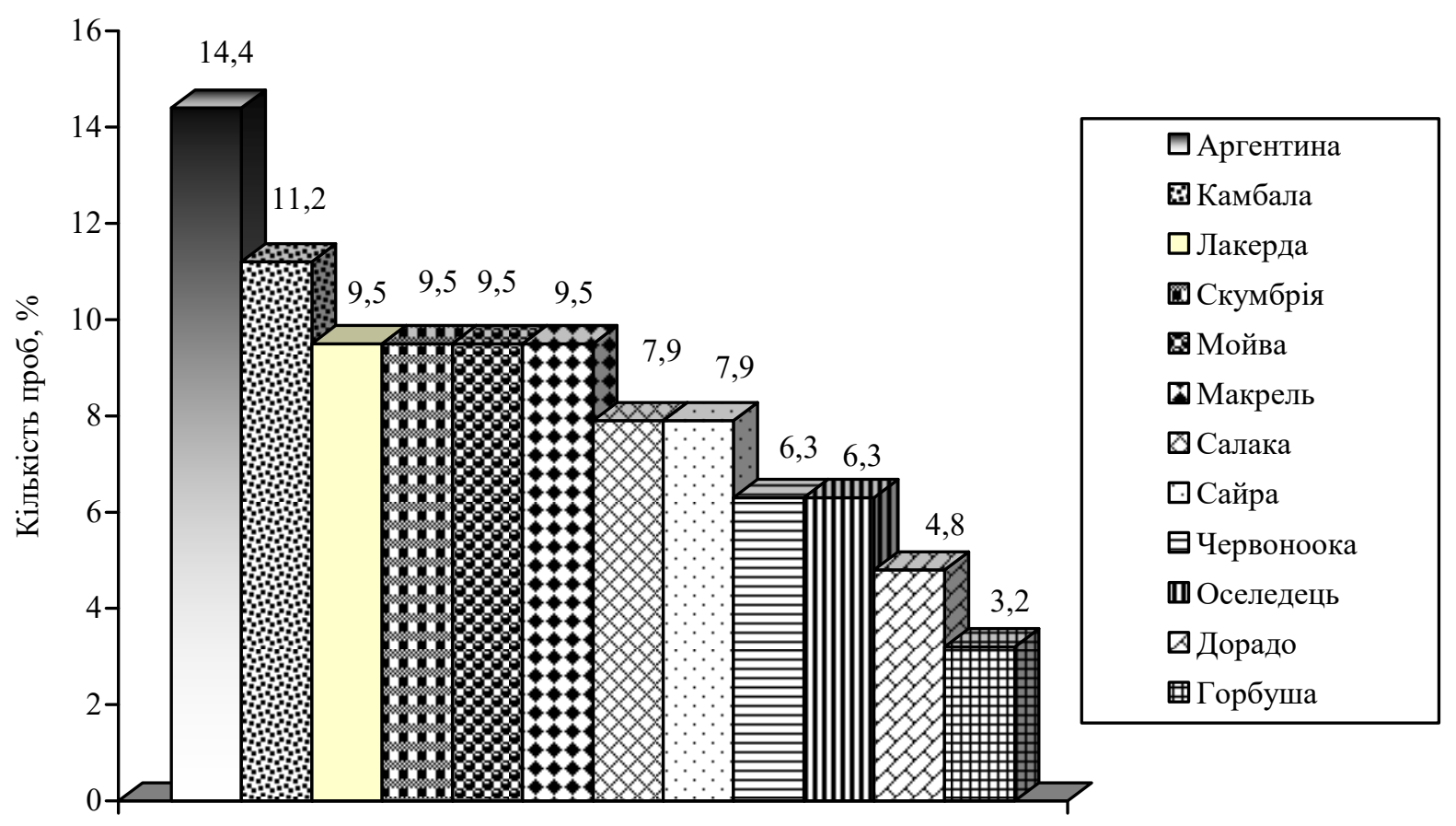

Рис. 3. Види риби, які найчастіше містили антибактеріальні субстанції

Найчастіше нами в імпортованій в Україну замороженій рибі виявляли антибіотики-аміноглікозиди (апраміцин, канаміцин, гентаміцин, спектиноміцин, паромоміцин, дигідрострептоміцин) - 46,4 \pm 0,7\% випадків та налідиксову кислоту в $20 \%$ випадків досліджених проб. Про значне використання у тваринництві та птахівництві антибіотиків-аміноглікозидів і макролітів повідомляють дані (Palyshniuk and Tkchuk, 2016), які виявляли залишки цих антибіотиків у продукції птахівництва. Водночас наші дослідження виявили наявність у рибі залишкових кількостей налідиксової кислоти, яку практично ніхто не визначає у продукції тваринного походження. Найбільш часто містили залишки антибактеріальних препаратів - це

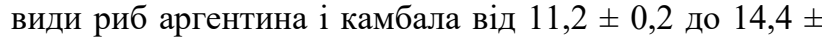
$0,2 \%$ випадків, а у найменшій кількості до $5 \%$ виявляли антимікробні субстанції у таких морських риб, як дорадо і горбуша. Встановлено наявність антибіотиків і антибактеріальних субстанцій у досліджених пробах риби, визначення, яких не передбачено Регламентом ЄС № 37/2010. Тому, враховуючи вище наведені результати досліджень, вважаємо необхідним передбачити національним законодавством дослідження 3 визначення залишкових кількостей антибактеріальних препаратів для підвищення безпечності риби, яка імпортується в Україну.

\section{Висновки}

Встановлено, що у торговельній мережі реалізується заморожена риба, яка у $10,5 \pm 0,3 \%$ містила залишки антибактеріальних субстанції. Найчастіше в імпортованій в Україну замороженій рибі виявляли протимікробні препарати із групи антибіотиків аміно- глікозидів (апраміцин, канаміцин, гентаміцин, спектиноміцин, паромоміцин, дигідрострептоміцин) в $46,4 \pm 0,7 \%$ випадків та надлидиксову кислоту в $19,0 \pm$ $0,2 \%$. Встановлено, що в найбільшій кількості виявляли антибактеріальні субстанції від 11,2 $\pm 0,2$ до $14,4 \pm 0,2 \%$ у видів риби аргентина та камбала, а в найменшій кількості до 5\% у таких морських риб, як дорадо і горбуша.

Перспективи подальших досліджень полягають у визначенні кількісного вмісту залишкових кількостей антибактеріальних субстанцій у замороженій рибі та внесення змін у нормативно-правові документи щодо контролю замороженої риби імпортного виробництва.

\section{References}

Akinbowale, O.L., Peng, H., \& Barton, M.D. (2007). Antimicrobial resistance in bacteria isolated from aquaculture sources in Australia. Journal of Applied Microbiology, 100(5), 1103-1113. doi: 10.1111/j.13652672.2006.02812.x.

Bayer, E.V., Novozhitskaya, Yu.N., Shevchenko, L.V., \& Mykhalska, V.M. (2017). Monitoring of residues of veterinary preparations in food products. Ukrainian Journal of Ecology, 7(3), 251-257. doi: 10.15421/2017_76.

Bhowmick, P.P., Khushiramani, R., Raghunath, P., Karunasagar, I., \& Karunasagar, I. (2008). Molecular typing of Vibrio parahaemolyticus isolated from seafood harvested along the south-west coast of India. Lett. Appl. Microbiol, 46, 198-204. doi: 10.1111/j.1472-765X.2007.02304.x.

Chen, H. (2014). Antibiotics in typical marine aquaculture farms surrounding Hailing Island, South China: Occurrence, bioaccumulation and human dietary expo- 
sure. Mar. Pollut. Bull., 3, 277-282. doi: 10.1016/j.marpolbul.2014.10.053.

Grigorakis, K., \& Rigos, G. (2011). Aquaculture effects on environmental and public welfare - the case of Mediterranean mariculture. Chemosphere, 85(6), 899919. doi: 10.1016/j.chemosphere.2011.07.015.

Grynevych, N., Sliusarenko, A., Dyman, T., Sliusarenko, S., Gutyj, B., Kukhtyn, M., Hunchak, V., \& Kushnir V. (2018). Etiology and histopathological alterations in some body organs of juvenile rainbow trout Oncorhynchus mykiss (Walbaum, 1792) at nitrite poisoning. Ukrainian Journal of Ecology, 8(1), 402-408. doi: $10.15421 / 2018 \_228$.

Kovalenko, V.L., Kovalenko, P.L., Ponomarenko, G.V., Kukhtyn, M.D., Midyk, S.V., Horiuk, Yu.V., \& Garkavenko, V.M. (2018). Changes in lipid composition of Escherichia coli and Staphylococcus areus cells under the influence of disinfectants Barez, Biochlor and Geocide. Ukrainian Journal of Ecology, 8(1), 402-408. doi: 10.15421/2018_248.

Kosenko, Yu.M., Tkachenko, V.Ī., \& Lapin, O.V. (2002). Monitorynh zalyshkiv veterynarnykh preparativ $u$ kharchovykh produktakh. Naukovyi visnyk Lvivskoi derzhavnoi akademii veterynarnoi medytsyny, 2, 4(5), 202-207 (in Ukrainian).

Kukhtyn, M., Berhilevych, O., Kravcheniuk, K., Shynkaruk, O., Horiuk, Y., \& Semaniuk, N. (2017). Formation of biofilms on dairy equipment and the influence of disinfectants on them. Eastern-European journal of Enterprise Technologies, 5, 89, 26-33. doi: 10.15587/1729-4061.2017.110488.

Palyshniuk, K, \& Tkchuk, S. (2016). The amino acid composition of broiler chickens meat after oral administration "Dankosan-50". Suchasne ptakhivnytstvo, 5(6), 38-40 (in Ukrainian).
Novozhytska, Yu.M., Ivanova, O.V., Stupak, O.M., Vasyliuk, V.V., Liniichuk, N.V., \& Korostinska, N.V. (2014). Vyznachennia antybiotykiv u produktsii tvarynnoho pokhodzhennia za dopomohoiu ridynnoho khromatomas-spektrometra. Kiev, DNDILDVSE (in Ukrainian).

Rico, A., Satapornvanit, K., Haque, M.M., Min, J., Nguyen, P.T., Telfer, T.C., \& Van den Brink, P.J. (2012). Use of chemicals and biological products in Asian aquaculture and their potential environmental risks: a critical review. Rev. Aquacult, 4(2), 75-93. doi: 10.1111/j.1753-5131.2012.01062.x.

Samanidou, V.F., \& Evaggelopoulou, E.N. (2007). Analytical strategies to determine antibiotic residues in fish. Journal of Separation Science, 30(16), 245-252. doi: $10.1002 /$ jssc.200700252.

Topic Popovic, N., Benussi Skukan, A., Dzidara, P., CozRakovac, R., Strunjak-Perovic, I., Kozacinski, L., Jadan, M., \& Brlek-Gorski, D. (2010). Microbiological quality of marketed fresh and frozen seafood caught off the Adriatic coast of Croatia. Veterinarni Medicina, 55(5), 233-241.

Usydus, Z., Szlinder-Richert, J., Polak-Juszczak, L., Kanderska, J., Adamczyk, M., \& Malesa-Ciecwierz, M. (2008). Food of marine origin: between benefits and potential risks. Food Chemistry, 111, 556-563. doi: 10.1016/j.foodchem.2008.04.018.

Zhang, R.J., Tang, J.H., Zheng, Li.J., Liu, Q., \& Chen, D. (2013). Antibiotics in the offshore waters of the Bohai Sea and the Yellow Sea in China: occurrence, distribution and ecological risks. Environ. Pollut, 174, 7177. doi: 10.1016/j.envpol.2012.11.008. 